\title{
Evaluation of Safety and Efficacy of Low Dose Atorvastatin in Bronchial
} Asthma

\author{
Geetha $\mathbf{R}^{1}$, Madhavan $S^{2}$, Parvathavarthini $S^{3}$ \\ ${ }^{1}$ Dr R Geetha, Assistant professor, Department of Pharmacology, Tagore Medical College \& Hospital Chennai, Tamil Nadu, \\ India. ${ }^{2} \mathrm{Dr} \mathrm{S}$ Madhavan, former professor, department of pharmacology, Stanley medical college \& hospital, Chennai, Tamil \\ Nadu, India. ${ }^{3}$ Dr. S Parvathavarthini, Professor \& HOD, department of Pharmacology, Tagore medical college \& hospital, \\ Chennai, Tamil Nadu, India.
}

Address for Correspondence: Dr R Geetha, Email: dr.geetharaghu@gmail.com

\begin{abstract}
Introduction: Statins are lipid lowering drugs with pleiotropic anti-inflammatory and immunomodulatory effects. We tested the hypothesis that short-term treatment with atorvastatin improves asthma control and airway inflammation in chronic asthma patients. Materials and Methods: This is a Prospective, Open label, Randomized, Controlled, Crossover study conducted at Stanley Medical College Hospital for 10 weeks. 60 patients with Chronic Asthma of more than 2 years duration were recruited. The patients were randomized to receive atorvastatin $10 \mathrm{mg}$ daily for 4 weeks separated by a $2-$ week washout period in a crossover fashion. Patients continued on their usual asthma drug treatment throughout the study. The effects of atorvastatin on absolute eosinophil count (AEC), C- reactive protein (CRP), Forced Expiratory Volume in 1 sec $\left(\mathrm{FEV}_{1}\right)$ were analyzed. Results: Data analysis revealed that no significant differences in forced expiratory volume in the first second $\left(\mathrm{FEV}_{1}\right)$, absolute eosinophil count and $\mathrm{C}$ - reactive protein levels in both control and study groups. Conclusion: Our study shows atorvastatin is not effective in the treatment of chronic asthma.
\end{abstract}

Key words: Asthma, Atorvastatin, Anti-inflammatory, Lung function, Statin

\section{Introduction}

Bronchial asthma is a very common disorder of airways. It affects about 300 million people worldwide, with a mortality rate of about 250,000 annually [1]. It is prevalent in both tropical and temperate regions. In tropical regions climate change and allergens may play a role in the causation of bronchial asthma. In temperate regions food habits, allergens and other environmental pollutants may be the causative factors.

Asthma is defined as chronic inflammatory disorder of airways that causes recurrent episodes of wheezing, breathlessness, chest tightness and cough, particularly at night or in the early morning. These symptoms are associated with variable airflow limitation that is at least partly reversible, either spontaneously or with treatment. There is associated increase in airway responsiveness, i.e. broncospasm to a variety of stimuli [2].

The inflammation involves many cell types like are Mast cells, Macrophages, Dendritic cells, Eosinophils,

Manuscript received: $4^{\text {th }}$ Aug 2014

Reviewed: $10^{\text {th }}$ Aug 2014

Author Corrected: $16^{\text {th }}$ Aug 2014

Accepted for Publication: $7^{\text {th }}$ Sept 2014
Neutrophils, T- lymphocytes and Structural cells. Also numerous inflammatory mediators like Cytokines, Chemokines, Histamine, Leukotrines, PAF, Prostanoids, Kinnins are involved [3], but how the inflammatory cells and the mediators are linked together in the causation of bronchial hyperactivity is not fully understood.

Treatment of bronchial asthma mainly constitutes of correcting the bronchospasm and the control of airway smooth muscle tone using, bronchodilators, Leukotriene antagonists, Mast cell stabilizers, Corticosteroids and Anti IgE antibody [4]. Even though many drugs with different mechanisms of action are available, but none of them are able to prevent asthma completely. This shows that various factors are involved in the pathogenesis of asthma. Since it is a disabling disorder, new drugs which reduce the severity of asthma are always in demand.

Statins are HMG CoA reductase inhibitors. They competitively inhibit the conversion of $\mathrm{HMG}-\mathrm{CoA}$ to Mevalonate and therefore deplete the intracellular supply of cholesterol by inhibiting its biosynthesis [4]. Statins 
are prescribed to treat atherosclerotic diseases due to their lipid lowering effect $[5,6]$, but studies have shown that some clinical benefits of statin therapy are due to mechanisms independent of their cholesterol lowering effects[7-9]. The pleiotropic anti-inflammatory and immune-omodulatory effects of statin have been widely described [10-12]. Statins lower C- reactive protein, a key indicator of inflammation and an independent risk factor for cardiovascular diseases. Reduction in CRP is due to its ability to reduce the production of IL -6 which is responsible for the acute phase CRP response [13].

Statins may reduce inflammation by Modulating the cholesterol content which reduces the stability of lipid raft formation; this affects the activation and regulation of immune cells, and also inhibits the signaling molecules which causes down regulation of gene expression. Both these effects lead to reduced expression of cytokines, chemokines and adhesion molecules, with effects on cell apoptosis or proliferation [13].

An alternative or additional cytokine synthesis pathway is the mevalonate synthetic pathway mediated by HMGCoA reductase, which is crucial for the biosynthesis of isoprenoids essential for normal cellular proliferation and activity. These isoprenoids prenylate proteins through covalent links gets attached to the lipid rafts and these prenylated proteins play an important role in the regulation of cell growth, cell secretion and signal transduction. Thus, by inhibiting prenylation, statins affect many cell processes involved in inflammation [13].

Statins also have Anti-oxidant effects and ability to scavenge oxygen derived free radicals which are responsible for many pathophysiological changes in chronic inflammatory airway diseases [14].

The potential benefits of statin therapy on the inflammatory airway diseases were demonstrated in experimental models of allergic airway diseases $[15,16]$. A retrospective study conducted by Stanek et al showed that statin therapy was associated with fewer asthma related hospitalizations or emergency visits [17] and also reduces decline in lung function [18]. Since inflammation plays a significant role in bronchial asthma, the aim of this study is to find out, if Statins are having a beneficial role to play in bronchial asthma in virtue of its Antiinflammatory and Immunomodulatory effects.

\section{Materials and Methods}

This is a Prospective, Open label, Randomized, Controlled Crossover, study which was conducted at the outpatient department of allergy and asthma clinic,
Stanley Medical College Hospital, Chennai. The study was started after obtaining approval by the Institution Ethics Committee of Stanley Medical College and hospital.

\section{Inclusion criteria}

- Chronic moderate- severe asthma of more than 2 years duration.

- Both male and female patients.

- Age 20 - 40 years.

- Nonsmokers.

- Those willing to sign informed written consent.

\section{Exclusion criteria}

- Age below 20 years and above 40 years.

- Patients with COPD, Pulmonary TB, Cardiovascular diseases, Epilepsy, Bleeding disorders

- Pregnant and lactating women.

- Patient already on statin therapy

- Previous statin sensitivity, myopathy

- Patients on drugs known to cause interactions with statin

- Patients with history of liver disease or jaundice

- Those who are on drug treatment for other coexisting diseases like Diabetes mellitus, Hypertension etc.

100 patients were screened; asthma diagnosis was confirmed by the pulmonologist on the basis of the spirometry and clinical symptoms. 60 patients were recruited on the basis of the selection criteria, the purpose, procedure and benefits of the study were explained in detail to the participants and then written informed consent was obtained in their own language.

The selected participants were then randomly allocated into two groups; each containing 30 patients using a random table.

This study was conducted as Trial-I and Trial-II, the study duration was 10 weeks for each patient.

Trial-I was divided into 2 groups.

Group A: In this group, 30 patients were included who received the standard therapy (Salbutamol 4mg twice daily and Aminophylline 100mg thrice daily) which they have already been taking for the past 3 months, these drugs were given for 4 weeks and this group served as the control group.

Group B: In this group 30 patients were included. In addition to the standard therapy (Salbutamol 4mg twice daily and Aminophylline 100mg thrice daily), Atorvastatin $10 \mathrm{mg}$ per day at bed time was added for 4 
weeks and this group served as the study group. After the study period of 4 weeks, a washout period of 2 weeks was given to each group and during this washout period, the patients in both groups of TRIAL-I were allowed to take only the routine drugs for Bronchial Asthma.

\section{Trial-II}

This is a crossover study which was conducted after a washout period of 2 weeks.

The TRIAL-I control group who received the standard therapy (Salbutamol 4mg twice daily and Aminophylline $100 \mathrm{mg}$ thrice daily), now in addition received Atorvastatin $10 \mathrm{mg}$ once a day for a period of 4 weeks. This group becomes the study group.

The TRIAL- I study group, who in addition to Salbutamol $4 \mathrm{mg}$ andAminophylline $100 \mathrm{mg}$, received Atorvastatin $10 \mathrm{mg}$ now becomes the control group receiving only the routine drugs for asthma.

Before starting the therapy, the patients were assessed for the following outcomes - Detailed medical history, physical examination, routine heamatological and biochemical parameters were done. $\mathrm{FEV}_{1}$, Absolute Eosinophil count and C-reactive protein were estimated in all the patients in both the groups at the beginning, end of $2^{\text {nd }}$ week and at the end of $4^{\text {th }}$ week of the study. Lipid profile, SGOT, SGPT were done in the control group before starting the therapy. Whereas in the study group, where the patients received Atorvastatin, lipid profile, SGOT and SGPT were done at the beginning, end of $2^{\text {nd }}$ week and at the end of $4^{\text {th }}$ week to rule out any drug related unwanted effects. When the groups were crossed over, investigations were repeated appropriately. All 60 patients completed the study. The data obtained at the end of this study was analyzed using SPSS software version 16. The tests used were - Student independent ' $t$ ' test, chi square test, Oneway ANOVA F- test and Repeated measures of ANOVA test. $\mathrm{P}$ value $\leq 0.05$ was considered significant.

\section{Results}

This study was conducted to find out, if the Antilipidaemic drug Atorvastatin is really having any therapeutic effect in patients suffering from chronic bronchial asthma. It is a prospective, open label, randomized, controlled, crossover study. Out of the 100 patients screened, 5 patients were smokers, 20 had dyslipidemia, 2 were diabetic, 3 were already on statin therapy, 2 had elevated liver enzymes and 8 were not willing to participate. These patients were excluded from the study. A total of 60 patients were included in the study as per the selection criteria. The study was conducted as 2 trials with 2 groups in each trial for a period of 10 weeks for each patient.

\section{Age and sex distribution:}

The age distribution was analyzed by student independent $t$ test. There was a even distribution of age in both the groups, the mean age of the participants in the control and the study group was 31.10 years $( \pm 5.87)$ and 31.5 years $( \pm 6.26)$ respectively. Majority of the study participants were females, $73.3 \%$ in Group A and 70\% in Group B. Statistical analysis was done by chi square test and there was no significant difference between the groups.

\section{Results of trial: I}

The parameters analyzed: Absolute Eosinophil Count (AEC), C- reactive protein (CRP), Forced Expiratory Volume in 1 second $\left(\mathrm{FEV}_{1}\right)$

Table 1: Absolute Eosinophil Count (AEC)

\begin{tabular}{|c|c|c|c|c|c|c|c|c|}
\hline & \multicolumn{2}{|c|}{ AEC OWK } & \multicolumn{2}{|c|}{ AEC $2^{\text {nd }} W K$} & \multicolumn{2}{|c|}{ AEC $4^{\text {th }}$ WK } & \multirow{2}{*}{$\begin{array}{l}\text { Oneway } \\
\text { ANOVA F-test }\end{array}$} & \multirow{2}{*}{$\begin{array}{l}\text { Repeated Measures } \\
\text { of ANOVA }\end{array}$} \\
\hline & Mean & SD & Mean & SD & Mean & SD & & \\
\hline Control & 465.13 & 49.67 & 466.40 & 48.95 & 465.00 & 49.06 & $\mathrm{~F}=0.02 \mathrm{P}=0.99$ & $\begin{array}{l}\text { Between groups } \\
\mathrm{F}=1.79 \mathrm{P}=0.19\end{array}$ \\
\hline Study & 457.83 & 56.73 & 449.87 & 53.02 & 436.40 & 46.60 & $\begin{array}{l}\mathrm{F}=13.44 \\
\mathrm{P}=0.001 *\end{array}$ & $\begin{array}{l}\text { Within group } \\
\mathrm{F}=52.43^{*} \\
\mathrm{P}=0.001\end{array}$ \\
\hline $\begin{array}{l}\text { Student } \\
\text { independent t-test }\end{array}$ & \multicolumn{2}{|l|}{$\begin{array}{l}t=0.53 \\
P=0.60\end{array}$} & \multicolumn{2}{|l|}{$\begin{array}{l}\mathrm{t}=1.25 \\
\mathrm{P}=0.25\end{array}$} & \multicolumn{2}{|l|}{$\begin{array}{l}\mathrm{t}=2.31 * \\
\mathrm{P}=0.02\end{array}$} & & \\
\hline
\end{tabular}

*Significant

The Table 1 shows the mean absolute eosinophil count done in the control and study group at $0,2^{\text {nd }}$ and $4^{\text {th }}$ week. it is evident from the table that there was no statistically significant difference among the groups at the baseline and at the end 
of the $2^{\text {nd }}$ week; statistically highly significant difference was seen in the study group when compared with the control group at the end of the $4^{\text {th }}$ week.

Table 2: C Reactive Protein (CRP)

\begin{tabular}{|c|c|c|c|c|c|c|c|c|}
\hline & \multicolumn{2}{|c|}{ CRP OWK } & \multicolumn{2}{|c|}{ CRP 2 ${ }^{\text {nd }}$ WK } & \multicolumn{2}{|c|}{ CRP $4^{\text {th }}$ WK } & \multirow{2}{*}{$\begin{array}{l}\text { Oneway } \\
\text { ANOVA F-test }\end{array}$} & \multirow{2}{*}{$\begin{array}{l}\text { Repeated Measures } \\
\text { of ANOVA }\end{array}$} \\
\hline & Mean & SD & Mean & SD & Mean & SD & & \\
\hline Control & 7.40 & 6.81 & 7.20 & 4.83 & 7.00 & 4.75 & $\mathrm{~F}=0.05 \mathrm{P}=0.96$ & $\begin{array}{l}\text { Between groups } \\
\mathrm{F}=2.61 \mathrm{P}=0.11\end{array}$ \\
\hline Study & 7.20 & 5.98 & 6.50 & 3.58 & 6.20 & 2.91 & $\mathrm{~F}=0.41 \mathrm{P}=0.55$ & $\begin{array}{l}\text { Within group } \\
\mathrm{F}=1.76 \\
\mathrm{P}=0.17\end{array}$ \\
\hline $\begin{array}{l}\text { Student independent } \\
\text { t-test }\end{array}$ & $\begin{array}{l}\mathrm{t}=0.12 \\
\mathrm{P}=0.90\end{array}$ & & $\begin{array}{l}\mathrm{t}=0.64 \\
\mathrm{P}=0.5\end{array}$ & & $\begin{array}{l}\mathrm{t}=0.79 \\
\mathrm{P}=0.4\end{array}$ & & & \\
\hline
\end{tabular}

The Table 2 depicts the mean C- reactive protein levels done in control and study groups at $0,2^{\text {nd }}$ and $4^{\text {th }}$ week. There was no statistically significant difference among the groups at the baseline and at the end of the $2^{\text {nd }}$ and $4^{\text {th }}$ week.

Table 3: Forced Expiratory Volume in 1 Sec $\left(F_{E V}\right)$

\begin{tabular}{|c|c|c|c|c|c|c|c|c|}
\hline & \multicolumn{2}{|c|}{$\mathrm{FEV}_{1} 0 \mathrm{WK}$} & \multicolumn{2}{|c|}{$\mathrm{FEV}_{1} 2^{\text {nd }} \mathrm{WK}$} & \multicolumn{2}{|c|}{$\mathrm{FEV}_{1} 4^{\text {th }} \mathrm{WK}$} & \multirow{2}{*}{$\begin{array}{l}\text { One way } \\
\text { ANOVA } \\
\text { F-test }\end{array}$} & \multirow{2}{*}{$\begin{array}{l}\text { Repeated Measures } \\
\text { of ANOVA }\end{array}$} \\
\hline & Mean & SD & Mean & SD & Mean & SD & & \\
\hline Control & 63.50 & 10.55 & 63.83 & 10.78 & 64.23 & 10.23 & $\begin{array}{l}F=0.03 \\
P=0.96\end{array}$ & \multirow{2}{*}{$\begin{array}{l}\text { Between groups } \\
\mathrm{F}=1.87 \mathrm{P}=0.18 \\
\text { Within group } \\
\mathrm{F}=102.78^{*} \\
\mathrm{P}=0.001\end{array}$} \\
\hline Study & 64.67 & 12.18 & 67.73 & 11.23 & 68.13 & 10.44 & $\begin{array}{l}\mathrm{F}=2.624 \\
\mathrm{P}=0.07\end{array}$ & \\
\hline $\begin{array}{l}\text { Student } \\
\text { independent t-test }\end{array}$ & \multicolumn{2}{|l|}{$\begin{array}{l}\mathrm{t}=0.39 \\
\mathrm{P}=0.69\end{array}$} & \multicolumn{2}{|c|}{$\begin{array}{l}\mathrm{t}=1.37 \\
\mathrm{P}=0.18\end{array}$} & \multicolumn{2}{|c|}{$\begin{array}{l}\mathrm{t}=1.46 \\
\mathrm{P}=0.14\end{array}$} & & \\
\hline
\end{tabular}

Table 3 depicts the changes in the mean $\mathrm{FEV}_{1}$ done in both control and study group at $0,2^{\text {nd }}$ and $4^{\text {th }}$ week. There was no statistically significant difference among the groups at the baseline and at the end of the $2^{\text {nd }}$ and $4^{\text {th }}$ week.

\section{Results of Trial - II}

This is a Crossover study; the patients were switched to the other group after a washout period of 2 weeks. The groups were treated with the respective drugs for a period of 4 weeks. The parameters analysed were: Absolute Eosinophil Count (AEC), C- reactive protein (CRP), Forced Expiratory Volume in 1 second $\left(\mathrm{FEV}_{1}\right)$ at baseline, at the end of $2^{\text {nd }}$ and $4^{\text {th }}$ week, as it was done in Trial-I

Table 4: Absolute Eosinophil Count (AEC)

\begin{tabular}{|c|c|c|c|c|c|c|c|c|}
\hline & \multicolumn{2}{|c|}{ AEC $0 \mathrm{WK}$} & \multicolumn{2}{|c|}{$\mathrm{AEC} 2^{\text {nd }} \mathrm{WK}$} & \multicolumn{2}{|c|}{$\mathrm{AEC} 4^{\text {th }} \mathrm{WK}$} & \multirow{2}{*}{$\begin{array}{l}\text { Oneway } \\
\text { ANOVA } \\
\text { F-test }\end{array}$} & \multirow{2}{*}{$\begin{array}{l}\text { Repeated } \\
\text { measures of } \\
\text { ANOVA }\end{array}$} \\
\hline & MEAN & SD & MEAN & SD & MEAN & SD & & \\
\hline CONTROL & 464.47 & 48.56 & 456.00 & 46.72 & 455.40 & 44.56 & $\begin{array}{l}\mathrm{t}=0.39 \\
\mathrm{P}=0.65\end{array}$ & $\begin{array}{l}\text { Between } \\
\text { groups } \\
\mathrm{F}=1.73 \mathrm{P}=0.18\end{array}$ \\
\hline STUDY & 460.67 & 47.24 & 438.13 & 46.70 & 422.73 & 46.24 & $\begin{array}{l}\mathrm{t}=6.43 \\
\mathrm{P}=0.01 *\end{array}$ & $\begin{array}{l}\text { Within group } \\
\mathrm{F}=82.08^{*} \\
\mathrm{P}=0.001\end{array}$ \\
\hline $\begin{array}{l}\text { Student } \\
\text { independent t-test }\end{array}$ & \multicolumn{2}{|l|}{$\begin{array}{l}\mathrm{t}=1.10 \\
\mathrm{P}=0.27\end{array}$} & \multicolumn{2}{|l|}{$\begin{array}{l}\mathrm{t}=1.48 \\
\mathrm{P}=0.14\end{array}$} & \multicolumn{2}{|l|}{$\begin{array}{l}\mathrm{t}=2.86^{*} \\
\mathrm{P}=0.02\end{array}$} & & \\
\hline
\end{tabular}

*Significant 
Table 4 shows the mean absolute eosinophil count done in both groups at $0,2^{\text {nd }}$ and $4^{\text {th }}$ week. No significant difference was seen among the groups at the baseline and at the end of the $2^{\text {nd }}$ week; statistically highly significant difference was seen in the study group when compared with the control group at the end of the $4^{\text {th }}$ week.

Table 5: C - Reactive Protein (CRP)

\begin{tabular}{|c|c|c|c|c|c|c|c|c|}
\hline & \multicolumn{2}{|c|}{ CRP 0 WK } & \multicolumn{2}{|c|}{ CRP $2^{\text {nd }}$ WK } & \multicolumn{2}{|c|}{ CRP $4^{\text {th }}$ WK } & \multirow{2}{*}{$\begin{array}{l}\text { Oneway } \\
\text { ANOVA } \\
\text { F-test }\end{array}$} & \multirow{2}{*}{$\begin{array}{l}\text { Repeated } \\
\text { measures of } \\
\text { ANOVA }\end{array}$} \\
\hline & MEAN & $\mathrm{SD}$ & MEAN & SD & MEAN & SD & & \\
\hline CONTROL & 6.10 & 2.91 & 5.80 & 2.27 & 5.70 & 2.58 & $\begin{array}{l}\mathrm{F}=0.15 \\
\mathrm{P}=0.88\end{array}$ & $\begin{array}{l}\text { Between } \\
\text { groups } \\
\mathrm{F}=2.77 \mathrm{P}=0.10\end{array}$ \\
\hline STUDY & 6.60 & 4.55 & 5.40 & 2.44 & 5.00 & 2.44 & $\begin{array}{l}\mathrm{F}=1.11 \\
\mathrm{P}=0.33\end{array}$ & $\begin{array}{l}\text { Within group } \\
\mathrm{F}=1.81 \\
\mathrm{P}=0.19\end{array}$ \\
\hline $\begin{array}{l}\text { Student } \\
\text { independent } \\
\text { t-test }\end{array}$ & $\begin{array}{l}\mathrm{t}=0.51 \\
\mathrm{P}=0.61\end{array}$ & & $\begin{array}{l}\mathrm{t}=0.44 \\
\mathrm{P}=0.66\end{array}$ & & $\begin{array}{l}\mathrm{t}=1.08 \\
\mathrm{P}=0.29\end{array}$ & & & \\
\hline
\end{tabular}

Table 5 depicts the mean C-reactive protein levels done in both study and control groups. No significant difference was seen between the groups at the baseline and at the end of the $2^{\text {nd }}$ and $4^{\text {th }}$ week.

Table 6: Forced Expiratory Volume in 1 Sec $\left(F_{E V}\right)$

\begin{tabular}{|c|c|c|c|c|c|c|c|c|}
\hline & \multicolumn{2}{|c|}{ FEV $10 W K$} & \multicolumn{2}{|c|}{$\mathrm{FEV}_{1} 2^{\text {nd }} \mathrm{WK}$} & \multicolumn{2}{|c|}{ FEV $_{1} 4^{\text {th }}$ WK } & \multirow{2}{*}{$\begin{array}{l}\text { Oneway } \\
\text { ANOVA } \\
\text { F-test }\end{array}$} & \multirow{2}{*}{$\begin{array}{l}\text { Repeated } \\
\text { Measures of } \\
\text { ANOVA }\end{array}$} \\
\hline & Mean & SD & Mean & SD & Mean & SD & & \\
\hline Control & 67.33 & 10.76 & 70.57 & 10.87 & 70.93 & 10.72 & $\begin{array}{l}\mathrm{F}=0.02 \\
\mathrm{P}=0.97\end{array}$ & \multirow{2}{*}{$\begin{array}{l}\text { Between groups } \\
F=1.65 \mathrm{P}=0.20 \\
\text { Within group } \\
F=45.57 * \\
P=0.001\end{array}$} \\
\hline Study & 64.17 & 10.23 & 66.93 & 9.67 & 70.63 & 9.36 & $\begin{array}{l}\mathrm{F}=3.01 \\
\mathrm{P}=0.06\end{array}$ & \\
\hline $\begin{array}{l}\text { Student } \\
\text { independent t-test }\end{array}$ & \multicolumn{2}{|c|}{$\begin{array}{l}\mathrm{t}=1.27 \\
\mathrm{P}=0.24\end{array}$} & \multicolumn{2}{|c|}{$\begin{array}{l}\mathrm{t}=1.36 \\
\mathrm{P}=0.17\end{array}$} & \multicolumn{2}{|c|}{$\begin{array}{l}\mathrm{t}=0.12 \\
\mathrm{P}=0.90\end{array}$} & & \\
\hline
\end{tabular}

*Significant

Table 6 shows the changes in the mean $\mathrm{FEV}_{1}$ levels done in both study and control groups at $0,2^{\text {nd }}$ and $4^{\text {th }}$ week. No statistically significant difference was seen among the groups at the baseline and at the end of the $2^{\text {nd }}$ and $4^{\text {th }}$ week.

\section{Discussion}

Asthma is a chronic respiratory disease caused by inflammation with swelling of the airways and constriction of the muscles of the bronchial passages [19]. Since inflammation plays a major role in the pathogenesis of asthma and as statins have unusual pleiotropic anti-inflammatory and immunomodulatory properties.

For this reason, this study was conducted to evaluate the safety and efficacy of low dose Atorvastatin in Bronchial asthma. This is a Prospective, Open label, Randomized, Controlled, Cross over study.
Atorvastatin was used as a single dose of $10 \mathrm{mg}$ for a period of 4 weeks, as it has side effects like myalgia and all the patients included in the study were with normal lipid levels, so it is not known what will be the effect of higher dose of Atorvastatin, especially when given on long term basis, on the lipid levels

Spirometric readings were taken in both control and study groups at 0,2 and 4 weeks, our results showed that addition of atorvastatin $10 \mathrm{mg}$ / day was not effective in improving the pulmonary volumes $\left(\mathrm{FEV}_{1}\right)$ in the study group as compared to the control group, in both Trial-I and Trial-II. Similar result was seen in the study

Available online at: www.ijmrr.in 424 | P a g e 
conducted by Hothersall et al. [20], where addition of atorvastatin $40 \mathrm{mg}$ /day to inhaled corticosteroids caused reduction in the number of macrophages in the sputum, but produced no improvement in the control of asthma symptoms.

No significant effect was seen in the absolute eosinophil count at the end of $2^{\text {nd }}$ week, but statistically highly significant difference was seen in the study group at the end of the $4^{\text {th }}$ week in both the Trials.

C-reactive protein is a non-specific marker of inflammation and is useful in determining the disease progression or the effectiveness of the treatment. In both the trials, there was not much difference in the $\mathrm{C}$-reactive protein levels at the end of $2^{\text {nd }}$ week and $4^{\text {th }}$ week in the study group as compared to the control group.

Our results were consistent with Menzies et al [21] who performed a crossover trial with simvastatin ( 2 weeks at $20 \mathrm{mg}$ daily and 2 weeks at $40 \mathrm{mg}$ daily vs placebo with no washout period) in patients with mild to moderate asthma and were not able to show evidence of antiinflammatory effects of simvastatin.

Even though the therapeutic effects of statin was demonstrated in the murine model of allergic asthma in a mice sensitized with ovalbumin [16], but similar effectiveness was not reproduced in randomized clinical trials conducted in humans.

This was proved in our study were addition of atorvastatin $10 \mathrm{mg}$ daily along with the routine drugs in patients with asthma for 4 weeks was not able to produce any significant impact on the spirometric parameters and in asthma relief.

Perhaps higher dose, longer period of treatment may have yielded a different result or maybe the variables selected in this study were not sensitive enough to show improved asthma control. Limitations to our study were inability to do sensitive quantitative methods due to cost factors. Measurements with peak flow meter, high sensitivity Creactive protein test, sputum differential cell count and methacholine challenge test would have provided more informative results

However studies conducted by Braganza et al [22] showed that short term treatment with statins in smokers with mild to moderate asthma, could improve asthma quality of life. Study conducted by Thompson NC showed that cigarette smoking in asthma causes reduced sensitivity to inhaled corticosteroids, addition of statins will restore the corticosteroid sensitivity [23] by increased induction of indolamine 2,3-dioxygenase leading to increased secretion of the anti-inflammatory cytokine IL -10 [24] or by restoring HDAC activity [25].

Also studies have demonstrated that obesity is associated with poor asthma control and decreased response to treatment with Inhaled corticosteroids [26, 27], as statins are lipid lowering agents; their addition may be beneficial in obesity related asthma, as seen in a retrospective study conducted in patients with severe asthma who were obese [28].

This shows that the anti-inflammatory property of statins is beneficial in only certain subpopulation of asthmatics like smokers and obese individuals who respond poorly to inhaled corticosteroids, so further studies should be conducted in these subpopulations.

\section{Adverse events}

No major adverse events were noted during the study period. Blood investigations SGPT, SGOT, blood urea and serum creatinine were within normal limits in both groups. Minor adverse effects like nausea, dyspepsia and headache were equally distributed among the study groups which did not need drug discontinuation or any treatment to resolve the adverse effects.

\section{Conclusion}

In conclusion atorvastatin administered in a dose of $10 \mathrm{mg}$ has failed to produce appreciable beneficial effects in chronic asthma patients. Its effectiveness in certain specific subpopulations of asthma like smokers and obese individuals who respond poorly to inhaled corticosteroids should be investigated.

\section{Funding: Nil}

\section{Conflict of interest: Nil}

Permission from IRB: Yes

\section{References}

1. Global strategy for asthma management and prevention [internet] 2010. [updated 2012, cited 2011 june 10]. Available at http://www.ginasthma.org.

2. Fraser RS, Pare PD. Asthma. In: Fraser RS, Pare PD, Neil Colman, Nestor L. Muller (eds.) Diagnosis of diseases of the chest. $4^{\text {th }}$ ed. Philadelphia: W.B. Saunders; 2004. p2077.

3. Peter J. Barnes. Asthma. Anthony S. Fauci, Dennis L. Kasper, Dan L. Longo, Eugene Braunwald, Joseph 
Loscalzo, S.L. Hauser (eds.) Harrison's: Principles of Internal Medicine. $17^{\text {th }}$ ed. New york: Mc Graw Hill; 2008. p1598 - 1599 .

4. Tripathi KD. Drugs for bronchial asthma. Essentials of Medical Pharmacology. $6^{\text {th }}$ ed. New Delhi: Jaypee publishers; 2008. p217 - 226.

5. Maron DJ, Fazio S, Linton MF. Current perspectives on statins. Circulation. 2000; 101(2): 207- 213.

6. Shepherd J, Cobbe SM, Ford I, Isles CG, Lorimer AR, MacFarlane PW. Prevention of coronary heart disease with pravastatin in men with hypercholesterolemia. N Engl J Med. 1995; 333(20): 1301- 1307.

7. Munford RS. Statins and the acute phase response. NEJM. 2001;344(26):2016 - 2018

8. Albert MA, Danielson E, Rifai N, Ridker PM. Effect of statin therapy on C-reactive protein levels: the pravastatin inflammation /CRP evaluation (PRINCE): a randomized trial and cohort study. JAMA. 2001; 286 (1): $64-70$.

9. Ridker PM, Rifai N, Pfeffer MA, Sacks F, Braunwald E. Long-term effects of pravastatin on plasma concentration of C-reactive protein. Circulation. 1999; 100 (3): $230-235$.

10. Takemoto M, Liao JK. Pleiotropic effects of 3hydroxy-3-methyl glutaryl co-enzyme A reductase inhibitors. Arterioscler ThrombVasc Biol. 2001; 21(11): $1712-1719$

11. Kwak B, Mulhaupt F, Myit S, Mach F. Statins as a newly recognized type of immunomodulator. Nat Med. 2000; 6 (12): 1399 - 1402.

12. Sparrow CP, Burton CA, Hernandez M, Mundt S, Hassing H, Patel S 'et al'. Simvastatin has anti-inflammatory and antiatherosclerotic activities independent of plasma cholesterol lowering. Arterioscler Thromb Vasc Biol. 2001; 21(1): 115-21.

13. Hothersall E, McSharry C, Thomson NC. Potential therapeutic role for statins in respiratory disease. Thorax. 2006; 61(8):729-734.

14. Jarjour NN, Calhoun WJ. Enhanced production of oxygen radicals in asthma. J Lab Clin Med. 1994; 123(1): 131-136.
15. Kim DY, Ryu SY, Lim JE, Lee YS, Ro JY. Antiinflammatory mechanism of simvastatin in mouse allergic asthma model. Eur J Pharmacol 2007; 557(1):76 $-86$.

16. McKay A, Leung BP, McInnes IB, Thomson NC, Liew FY. A novel anti-inflammatory role of simvastatin in a murine model of asthma. J Immunol 2004; 172(5): 2903-8.

17. Stanek EJ, Aubert RE, Xia F, Frueh FW, Sanders C, Weiss ST et al. Impact of statin therapy on asthma-related event costs in adult asthma patients. Value Health 2009;12(3):A121-A122

18. Alexeeff SE, Litonjua AA, Sparrow D et al. Statin use reduces decline in lung function: VA Normative Aging Study. Am J RespirCrit Care Med. 2007; 176(8): 742 747.

19. William W. Busse, Sameer K. Mathur. Biology of Asthma. In: Alfred P. Fishman (eds.). $4^{\text {th }}$ ed. New York: Mc Graw Hill; 2008. p773-774.

20. Hothersall EJ, Chaudhuri R, McSharry C, Donnelly I, Lafferty J, McMahon AD. Effects of atorvastatin added to inhaled corticosteroids on lung function and sputum cell counts in atopic asthma. Thorax. 2008; 63(12): 10705.

21. Menzies D, Nair A, Meldrum KT, Fleming D, Barnes M, Lipworth BJ. Simvastatin does not exhibit therapeutic anti-inflammatory effects in asthma. J Allergy Clin Immunol 2007; 119 (2): 328-35.

22. Braganza G, Chaudhuri R, McSharry C, Weir CJ, Donnelly I, Jolly L et al. Effects of short-term treatment with atorvastatin in smokers with asthma-a randomized controlled trial. BMC Pulm Med. 2011; 11:16.

23. Thomson NC, Chaudhuri R: Asthma in smokers: challenges and opportunities. Curr Opin Pulm Med. 2009; 15(1):39-45.

24. Maneechotesuwan K, Ekjiratrakul W, Kasetsinsombat K, Wongkajornsilp A, Barnes PJ: Statins enhance the anti-inflammatory effects of inhaled corticosteroids in asthmatic patients through increased induction of indoleamine 2, 3-dioxygenase. J Allergy ClinImmunol 2010; 126(4):754-762.

25. N'Guessan PD, Riediger F, Vardarova K, Scharf S, Eitel J, Opitz B et al. Statins Control Oxidized LDL 
Mediated Histone Modifications and Gene Expression in Cultured Human Endothelial Cells. Arterioscler ThrombVascBiol. 2009; 29(3):380-386.

26. Lavoie KL, Bacon SL, Labrecque M, Cartier A, Ditto B. Higher BMI is associated with worse asthma control and quality of life but not asthma severity. Respir Med 2006; 100(4):648-657.
27. Forno E, Lescher R. Decreased response to inhaled steroids in overweight and obese asthmatic children. J Allergy ClinImmunol. 2011; 127(3):741-749.

28. Zeki AA, Oldham J, Wilson M et al: Statin use and asthma control in patients with severe asthma. BMJ open. 2013; 3(8)

\section{How to cite this article?}

Geetha R, Madhavan S, Parvathavarthini S. Evaluation of Safety and Efficacy of Low Dose Atorvastatin in Bronchial Asthma. Int J Med Res Rev 2014;2(5):420- 427. doi:10.17511/ijmrr.2014.i05.04 